\title{
PREPARATION OF AN AUTISTIC CHILD FOR SCHOOL
}

\author{
Aldo Špelić, $P h D$ \\ Department of Educational Sciences, \\ Juraj Dobrila University of Pula (Croatia) \\ e-mail: aspelic@unipu.hr \\ Martina Košeto \\ Department of Educational Sciences, \\ Juraj Dobrila University of Pula (Croatia) \\ e-mail: martina.koseto@hotmail.com
}

\begin{abstract}
S u m m ary
The aim of this paper is to present new opportunities of the individualized kindergarten teachers' approach in the preparation of an autistic child for school. The paper presents a case of an autistic child who, in addition to receiving individual psychotherapy treatment, was worked with individually by two kindergarten teachers to realise school preparation program. Through the implementation of the program, which was primarily based on the development of affective communication in a dyadic relationship with the autistic child, there were positive results in the child's affective attachment to the kindergarten teachers. These changes helped the child to adopt basic graphical motor skills, naming and social speech, and enabled him to attend regular elementary school. This article can be a stimulus to many other such approaches in the preparation of autistic children for their regular elementary education.
\end{abstract}

Key words: autism, pre-school, early child development

\section{Introduction}

Preparation of children for school is a very important aspect of educators' activities in kindergartens since the child's later success in elementary school education depends on it. From this preparation are usually excluded children with the autistic disorder, as there is a belief that it is not possible to achieve the desired results, with regard to their difficulties in establishing contact and their isolation, which are seen as consequences of different organic pathologies.

In this sense, the aim of the paper is to present the case of an autistic child, Antonio, who, in addition to his individual psychotherapy treatment and the individualized work with two educators, achieved very positive results in his preparation for elementary school. Through this case review the task is to highlight 
how appropriate individualized work of educators, with an emphasis on establishing quality affective relations, accompanied by the supervision of their work, can achieve positive results in the area of skills and knowledge of an autistic child necessary for joining primary school.

The problem of the autistic children's involvement in such programs is primarily determined by the general approach in the professional and scientific environment based on the unclear concepts of etiology of this disorder (Špelić, 2010). Speaking about problems of autistic children and possible therapeutic approaches, we mainly encounter particular focuses on a multitude of symptoms that have no common basis for understanding the psychopathology of autism. Thus, in the descriptions of this disorder, we meet many symptoms, such as aloofness and restraint from other people, the absence or underdevelopment of speech, avoidance of physical and visual contact, marked agitation and hyperactivity, lack of fear in dangerous situations, behavior as if they were deaf, laughing without apparent reason, playing strange games, food refusal, fixation on certain objects, resisting to any changes, and other occurrences. All of these autistic symptoms can usually be reduced to a triad of symptoms, which Kanner (1943) singled out as essential, namely: aloofness and absence of interest in the social environment, the absence of or underdeveloped speech and the existence of many stereotypical behaviors.

Experts mainly agree on the described autistic phenomenon, however, their disagreements arise with regard to the autistic etiology. Therefore, it is understandable that a large number of authors, as observed by Bujas-Perković and Tardi (2004), agree that the autistic disorder is the syndrome of different etiology but similar clinical pictures. With such an approach we are faced with a multitude of 'organic' theories that suggest genetic, metabolic, biochemical and neurological abnormalities as the basis of autistic manifestations. In this multitude of 'organic' theories of the autistic etiology, nowadays, 'psychological' theories are left in the background. This problem in the approach to understand autism I have elsewhere defined (Špelić, 2008) as the problem of 'splitting' that exists in the wider scientific and professional environment and as such it has restricted the occurrence of many psychological approaches in the treatment of autism.

The problem of splitting has been present from the very beginning of the definition of autism. In Kanner's first works $(1943,1949)$ we find some important observations about the lack of emotional warmth from parents in the development of 'early infantile autism' of their children, among which are extricated parental coldness, obsessive and mechanical type of relationship. But later Kanner (1969), influenced by the negative reaction in the wider American society, distanced himself from the previous concept of 'cold mothers' and claimed the "innate inability of children to form a common, biologically determined emotional contact with people, and that autistic children are born with innate physical and intellectual disabilities." In this way Kanner gave up 'psychological' concepts of autistic etiology. Particularly negative impact on the development of 'psychological' concepts of autism had Bettelheim (1967), who brought to its extreme the problem of 'refrigerator mother' by presenting an autistic child as an 'empty fortress' that has emerged in the family environment similar to emotional environments of concentration camps. 
Splitting of organic and psychological theory is still present in scientific and professional environment and extends to the level of absolute exclusivity. Thus, some authors (Herbert et al., 2002) considering two different concepts of the autistic etiology, suggest the need for separating fact from fiction with regard to the question of etiology and treatment of autism. In their representation of facts, the authors cite numerous studies that indicate the 'organic', namely neuro-biological and genetic causes of autism, considering all other theories as fiction. On the other hand, we meet authors (Zepf S., Zepf F., 2008) who deny the same facts, presenting the opposite results of other researches on similar samples. In addition to bringing into question a variety of different and mutually inconsistent 'organic' concepts of the autistic etiology, the same authors recognize the importance of early affective experiences in the development of intersubjectivity (Stern, 1985) for the emergence of autism. In that sense, I would single out the works of authors who perceive a negative impact of an early affective deprivation (Rutter et al., 1999) and the lack of early visual contact between the mother and the child (McDowell, 2004) in the early child's development that may lead to the autistic occurrence.

In relation to the problem of splitting, which exists between the two autistic concepts, we are often faced with different authors attempting to find a compromise. Thus, some authors (Nikolić, 1988) use some psychological concepts of autism in the psychotherapeutic approach, but at the same time they distance themselves from these concepts by mentioning possible minimal organ damages or metabolic dysfunctions. Some authors (Alvarez, 1992; Tustin, 1992), in order to avoid the confusion associated with the questions of autistic etiology and consequently psychotherapeutic approaches, recommend that the question of etiology should not be connected with the question of treatment, while others (Hallett, Viren, 2005; Harshman, 2002) suggest that, at least in the first step of therapeutic approaches, the questions of etiology should be ignored and the phenomenological approach used in understanding autism.

The 'psychological' approaches to the treatment of autistic children today are still dominated by the concepts of object relations theory of the British psychoanalytic school (Klein 1930, Meltzer 1975, Tustin 1972, Alvarez, 1992). In these concepts autism is understood as a failure of object relations development, namely the failure of differentiation of the self and the object, which is manifested in the weakness of the ego and the failure of adequate development of affectivecognitive relationship with the environment in the form of psychotic pathology. This failure in object relations' development is perceived as consequences of traumatic experience in the child's confrontations with separation experiences and sensations of the external world, which is determined by the mother's failures in care and protection during the feeding period.

Under the influence of these concepts, in contemporary psychotherapeutic approaches (Gomberoff M, Gomberoff L.P, 2000; Mori, 2001; Urwin, 2002; Barrows, 2002; Houzel, 2004, De Cesarei, 2005; Zepf S, Zepf D, 2008) the therapist's task can be expressed as 'make connection of threads of primary relationship and strengthen them in the therapeutic relationship which will enable 
the reconstruction of early separation trauma and further emotional development of autistic children' (De Cesarei, 2005)

Special approval of the 'psychological' concepts can be seen in the research of the School Children's Mental Health in London (The School of Infant Mental Health - London) founded in 1990. Notable are their observations on the first autistic signs in children who are only a few weeks old, who are defined as pre-autism (Aquarone, 2007). These were mostly children whose parents used to say 'I know something is wrong with the baby', which was expressed in constant inadequate forms of relating to persons, some specific gaze, unusual posture of the body, inadequate responses to the mother's voice and speech or extremely slow (inhibited) or accelerated (excited) ways of expressing affects. Important remark of Aquarone (2007) is that the signs of pre-autism are indicators of possible bad consequences, not disorder. After she intervened early in the form of 'opening channels of communication' between the mother and the child, many positive changes in these children's conditions were achieved and at the same time it facilitated further normal development of the child.

All these observations about the importance of 'psychological' factors in autistic development have stimulated my psychotherapeutic work with the autistic child Antonio and gave me the idea of including kindergarten teachers in the work with the autistic child. Through the build-up and maintenance of adequate affective (dyadic) relationship with the autistic child, they will implement the program of preparation for school.

\section{Case report of the autistic child}

Antonio was born in 1993. Pregnancy and birth were normal. Motor development was also normal. The child began to walk in his twelfth month and gained control of the sphincter in the second year. The first word emerged in his first year, while the formation of the first sentences occurred in the second year of the child's life. Before the changes the child developed bilingual naming. At the same time he showed interest in picture books and was able to name individual animals.

Changes in the child's abilities were preceded by a family trauma. All these changes started short after the illness and death of his grandfather on his mother's side. After that period the grandmother on his mother's side was diagnosed with cancer and the mother's brother was hospitalized with the diagnosis of paranoid psychosis. In this period, the mother was preoccupied with the disease of her father, mother and brother while the child was left to himself, mostly watching cartoons on television, which was followed by his lack of interest in the events in his environment, the occurrence of odd stereotyped behaviors and speech regression. During this period his father was preoccupied with his work in the tourism industry which further burdened the situation. Initial withdrawal was then followed by negativistic types of behavior. Since then the child had no longer used or wanted to repeat a single word, or call his parents 'mom' and 'dad'. At that time he started to communicate non-verbally with the parents leading them to the object of his interest. He gave up using words and pronouncing his own name and surname that had 
already been adopted. Also, he had difficulties in establishing and maintaining visual contact with other persons in his environment.

His games consisted mostly of stereotyped beating around with a stick, which produced a uniform, unpleasant noise. When the child was prohibited to do so he would briefly stop the activity with the onset of anxiety and then quickly continue to do the same. At home, as his mother observed, he stopped playing with dolls as he had done before and also stopped showing interest in cubes or some other toys with which he had played willingly earlier.

In the fourth year of life the child was enrolled in kindergarten (year 1997) which led to more prominent autistic symptoms. During this period the parents contacted experts for help regarding the changes they had identified in their child. As a result of the diagnostic procedure the disturbances of the child were defined by psychiatrists, psychologists and psychotherapists as a pervasive developmental disorder.

Based on this diagnosis, the same year (1997) the child received individual psychoanalytic psychotherapy. These autistic symptoms were understood as consequences of the separation trauma associated with his mother's mourning that was often established in the observation of autistic children as the cause or the forerunner of occurrence of autistic symptoms (Tustin, 1972; Gomberoff, M., Gomberoff, L.P, 2000; Houzel, 2004). The psychotherapeutic approach consisted of two individual sessions with the autistic child and one family session a week in which, except for his parents, the kindergarten teachers who worked with the child were also involved.

During the first three years of psychotherapeutic work with the autistic child certain positive changes were achieved, such as the establishment of visual contact and the exciting affective relationships with the autistic child, which were followed by the withdrawal of stereotyped behaviors. However, these changes were not accompanied by the changes in the child's behavior in the kindergarten. In meetings with the teachers I was mainly informed about his inability to fit in and to participate in games with other children. They described him as absent and self-oriented in a play that looked like a uniform manipulation with same objects. These child inabilities in communication and educational achievements were interpreted by them as a result of his 'mental retardation' and 'some unknown organic pathology', thus justifying the futility of my attempts to use certain 'psychological' approach in working with him. As a result of such an emotionally superficial and neglected access to the child, there was further deterioration in the child's state of mind occasionally expressed in psychotic anxiety states, followed by regression and difficulty in control.

Due to the parents' inability to change the kindergarten teachers' approach to autistic child, they decided, on my suggestion, to enrol Antonio in another kindergarten where a different approach would be used. Therefore, the parents moved from a town in Istria to Pula. In July 2000 the child was enrolled in a kindergarten in Pula, which applied a program prepared in accordance with the two kindergarten teachers, whose work I later supervised as the child psychotherapist. 
Within this approach, two kindergarten teachers were involved in everyday group work and one hour daily in individual work with the autistic child.

This 'new psychological' approach in the kindergarten in combination with the individual psychotherapeutic treatment led to significant changes in the autistic child with respect to his previously described autistic symptoms. As a result, after fifteen months of this program's implementation, the child managed to be included in regular elementary school with an adjusted program. During this period the child succeeded in developing abilities such as naming objects, letters and numbers and graphomotor skills associated with writing numbers and letters, all of which was accompanied by positive changes in speech.

\section{Specificities of kindergarten teachers' approach in working with the autistic child}

In the representation of specificities of the 'new' approach to the preparation of the autistic child for school, it is important to start with the observation of one of the kindergarten teachers involved in the program. In an interview with one of them, which has been recently conducted, she expressed initial fear associated with the acceptance of such a task. She explained that they both had fear of a possible onset of child anxiety and agitation, which created in them a sense of powerlessness and necessity to give up and pull out of such a program. These problems only stimulated them to prepare themselves for further work with the autistic child before his arrival in the kindergarten group. They searched the literature for more information about the autistic disorder and specific behaviors of autistic children. However, for them the greatest benefit was their participation in the family sessions with the parents of the autistic child and later in the supervisory sessions with the therapist of the autistic child. Only through supervision, namely going through certain specific situations, they were able to understand child's certain needs and how they have to meet and master the child's anxiety states and encourage desirable behaviors.

In the preparation of the kindergarten teachers for their work with Antonio I pointed out three major approaches in building and maintaining an adequate affective relationship with the autistic child. The first approach, and the most important one in the initial build-up of the relationship with the autistic child, was determined by establishing visual contact, in other words, it represents the effort of the kindergarten teachers to establish eye contact before any instructions or requests are given to the child. With such an approach a prerequisite was created for the development of mirroring transference (Kohut, 1990), which is the holder of some aspects of narcissistic experience, important in the development of the child's vitality and object orientation. This narcissistic experience in the later phase of the program has special importance as initiator and holder of the internalization process.

The second approach was determined by the kindergarten teachers' efforts that, in relation to the autistic child, they apply a more pronounced use of emotional reactions, namely, that any relation to the autistic child has to have an affective arousing meaning. This exciting aspect of the relationship with the autistic child 
(reclaiming) is recognized as an important factor in the psychological 'awakening' (Alvarez, 1992) and vitality development of the autistic child.

The third approach is determined by the requirement for constancy and persistence of the kindergarten teachers in the onset of anxiety and dissatisfaction of the autistic child. With this approach the kindergarten teachers meet the function of containing the child's anxiety (Bion, 1959), which allows him to develop the ability of mastering anxiety states without regressive shift or aggressive, uncontrolled behavior.

In this section, it is important to note that the kindergarten teachers working with the autistic child gradually succeeded in developing all these aspects of the relationship with the autistic child that resulted in increasing the child's orientation towards them, the emergence of his imitation and internalization of new forms of behaviors.

\section{Review of changes of the autistic child during the process of preparation for school}

In monitoring the child's changes during this period we used the diary kept by the kindergarten teachers who worked with the autistic child. The monitoring was from June 2000 to August 2001, from the time when the autistic child started attending the kindergarten until he no longer attended. In this period the interest was focused on the child's changes in the field of socialization by monitoring the development of emotional (dyadic) relationship of the autistic child with the kindergarten teachers and with other children in the kindergarten, then in the field of graphomotor skills by monitoring the development of drawing and writing abilities and in the field of speech by monitoring the development of naming ability and social speech.

Through the analysis of the diary I recognized the existence of three phases, which differ from each other in tasks and forms of the affective relationship of the autistic child and the kindergarten teachers. The first phase, which comprises the first month of the child's adjustment to kindergarten, is characterized by the initial state of anxiety accompanied by various forms of autistic behavior that is followed by the establishment of first aspects of a positive relationship, i.e. emotional connection between the autistic child and the kindergarten teachers. The second phase, which comprises the period from July to September 2000 is characterized by consolidation and development of connections between the autistic child and his kindergarten teachers. The third phase, which comprises the period from October 2000 until August 2001, is characterized by the adoption of certain new skills and knowledge, including the development of graph-motor abilities; naming objects, letters and numbers, as well as the development of social speech. 


\section{Changes in socialization}

In the diary of the kindergarten teachers there is an important record of the first day of the autistic child in the kindergarten. The child did not want to remain in the kindergarten, which he expressed by uncontrolled anger, shouting and throwing on the floor. In this initial period, the child avoided eye contact. He had frequent mood swings and was banging doors and other objects. In a situation of dissatisfaction he was screaming and waving his hands. In these initial contacts with the autistic child the kindergarten teachers felt helpless and unsuccessful in trying to approach him and attract his attention.

By comparison to other children's activities in the kindergarten, the child initially denied all forms of group activities. He tried to detach himself from a group of children at bedtime or during meals. During this period of 'loneliness' he would mostly play with his hands, namely his palms. Only gradually he began to play with cubes, arranging the ones of the same colour or mostly of two different colours. Also, he would play in his own special way with toys brought from home. These toys served as 'autistic objects' (Tustin, 1992).

In this first phase of adjustment, as observed by the kindergarten teachers, the child was trying to avoid a relationship with the kindergarten teachers and other children and also maintain his own state of boundlessness and omnipotence through repetitive motor activities. During this period the autistic child communicated with the teachers by gestures and mime. He did not use words. To teachers' requests he would respond with anger and inappropriate behaviors (throbbing, screaming) what looked like a response to an aspect of setting a limit to his untouchable omnipotence. In the situation when he was asked by the kindergarten teachers to eat or not to remove shoes in the park, he would react with revolt, crying, shouting and banging.

During this period the most important task of the kindergarten teachers was to establish and maintain a relationship with the autistic child. They were predominantly focused on establishing eye contact and giving affective encouragement to child's certain activities. Only after the established visual contact it was possible to make requests that would be accepted by the autistic child in a repetitive and echolalic way. Otherwise, he acted as if those requests did not exist. The established visual contact was followed by teachers' encouraging and rewarding of the child for using, mainly in a repetitive way, words in their relationship.

The shift from this first phase is mostly seen in the situation (from the record dated 23 June 2000) when the child went to the toilet and urinated outside the toilet. Faced with it, he reacted with discomfort and attempt to redeem himself. In this situation, he did not have usual reactions like anger and rage, rather shame and embarrassment. This event indicated the development of a new kind of relationship when the kindergarten teachers became an important (powerful) object for him.

These changes in the relations with the kindergarten teachers, which represented the beginning of the second phase of the relationship, gradually brought changes in the child's behavior by comparison to the usual activities in the kindergarten. These changes followed the autistic child's sitting at a table with other 
children. At the same time he began to eat food offered to other children, which was not the case at the beginning when he refused all food except bread and soup. He also started sleeping with other children in the room, which is something he had previously avoided.

During this period, progress was recognized in the child's growing ability to control anger in a situation of frustration. This progress was accompanied by increasing praises and rewards from the kindergarten teachers who encouraged bonding between them and the autistic child. At that time it was much easier to maintain his attention and also encourage his persistence in certain activities. During this period the kindergarten teachers noted that his attention span became longer and that certain individualized activities (exercises) could take up to 50 minutes.

Only with the increase of his connections with the kindergarten teachers and his control of rage and anger in situations of frustration, it was possible to start the third phase, which represents the period of education. Now it was possible to stimulate and direct the child in drawing (in the beginning he was only drawing default shapes until completely fulfilled), solving worksheets, learning names of new objects and writing letters. These changes in the child's behavior were followed by the acquisition of new knowledge and skills which will be presented in the following chapters.

During this period the relationship with other children in the kindergarten group did not significantly change, i.e. no bonds were formed with or interest shown toward any child in the kindergarten group. Positive changes were primarily recognized in the dyadic relations with the kindergarten teachers, while in relation to other children positive changes were recognized only at the end of his stay in the kindergarten. One can notice that during August 2001 he began to communicate verbally with other children in the kindergarten using simple sentences. At the same time it was noticed that his behavior in the group with other children became much more relaxed, without aggressive outbursts and with possible anger control in some frustrating situations.

\section{Changes in graphomotor skills}

On the child's arrival at the kindergarten he was not able to hold a pencil correctly or draw any basic geometric shape. He could only colour within a given area, which gave the impression of compulsory activities. This was expressed in a way that the child could not move to a new activity before he finished the colouring he had already begun. The first significant positive changes in the child's development of graphomotor skills followed after the establishment of proper capacity to hold a pencil (from the record of 19 July 2000). This change can be attributed to the previously observed changes in the emotional relationship between the child and the kindergarten teachers.

Real and noticeable changes in the graphomotor ability are recognizable only in the third period after October 2000 when the kindergarten teachers started individually working with him on the adoption of basic graphomotor skills. During 
the first two weeks of this approach the child began to draw correctly his first geometric shapes. Only then was he able to close the circle of his own, which was impossible earlier.

After that period they started solving worksheets with the child. In the beginning these worksheets were being solved in a disordered manner. The lines were uneven and over the set frame. With exercise and stimulation by the kindergarten teacher, the autistic child began to do everything more correctly; the default shapes became similar to letters. It was the first sign that he could start adopting letter writing (from the record of 11 October 2000).

At the beginning it was hard for him to adopt letter writing, but with time he adopted it well. The adoption of writing letters and numbers happened simultaneously with the adoption of their naming. The process of recognizing and naming letters, the autistic child adopted by linking the names of objects and initial letters, which were in his picture book "ABC". Numbers were recognised and their writing learned quickly. At the end of the process of preparation for school (from the record of June 2001) he was able to write letters and numbers very well and understand their meaning.

Figure 1, 2 - The works of the autistic child connected with the adoption of writing letters and numbers during the preparation program for school.
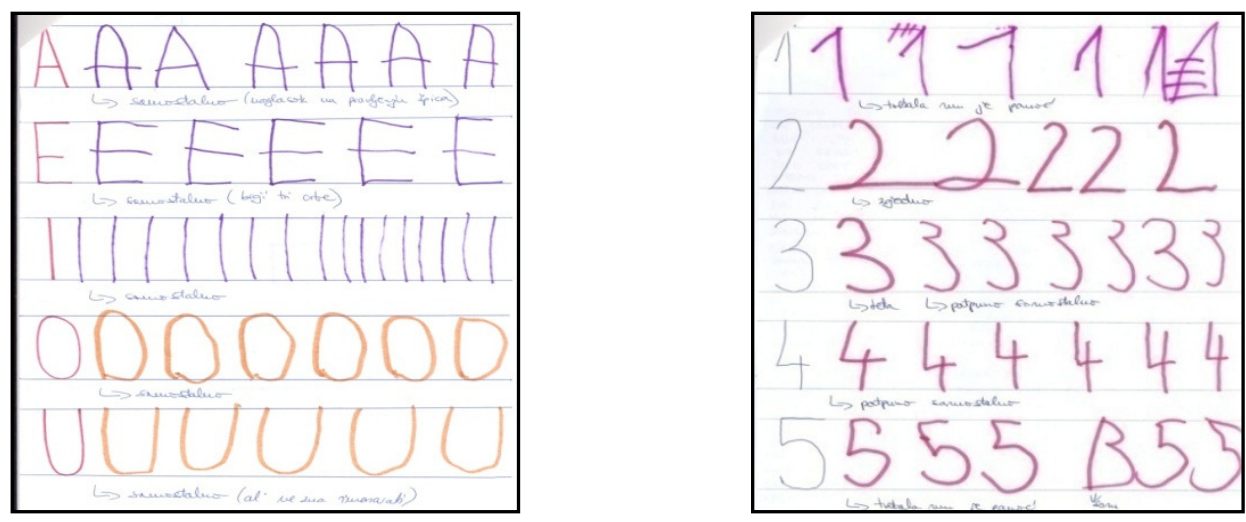

The development of the ability to write letters and numbers is visible in Figure 1 and 2. Figure 1 shows the work of the autistic child (from the record of 01 March 2001) in which we can recognize progress in writing letters started at the beginning of October 2000. Teachers' observations were that the child tried to make a correct top of the letter A, on which they placed major emphasis. Also, the observation was that the child wrote all the letters independently and that over time all the letters he wrote became a lot neater and more appropriate. Figure 2 shows the work of the child (from the records of 04 May 2001) in which we can recognize his progress in writing the numbers from 1 to 5 . During this period, the child wrote the numbers independently. The observation of the kindergarten teacher in class work with the autistic child was that at the beginning of these activities the child was not 
concentrated but with her help he succeeded in focusing himself on the set of activities. Then she recognized his problem in mixing and distinguishing letters and numbers. Thus, the number 5 recalled him of the letter B, so he spontaneously included it in the sequence of written numbers.

During the development of his ability to name and write letters and numbers, there was a visible change in his drawing. In relation to the initial scribbling and drawing on given surfaces, the child became quickly able to draw simple shapes with the help of the teachers who partly assisted and encouraged these activities (from the record of September 2000). In this way, he gradually began to draw increasingly complex default forms and later to draw assigned topics such as drawings of human bodies and house-flower-sun.

Figure 3, 4-The works of the autistic child connected with the adoption of drawings during the preparation program for school
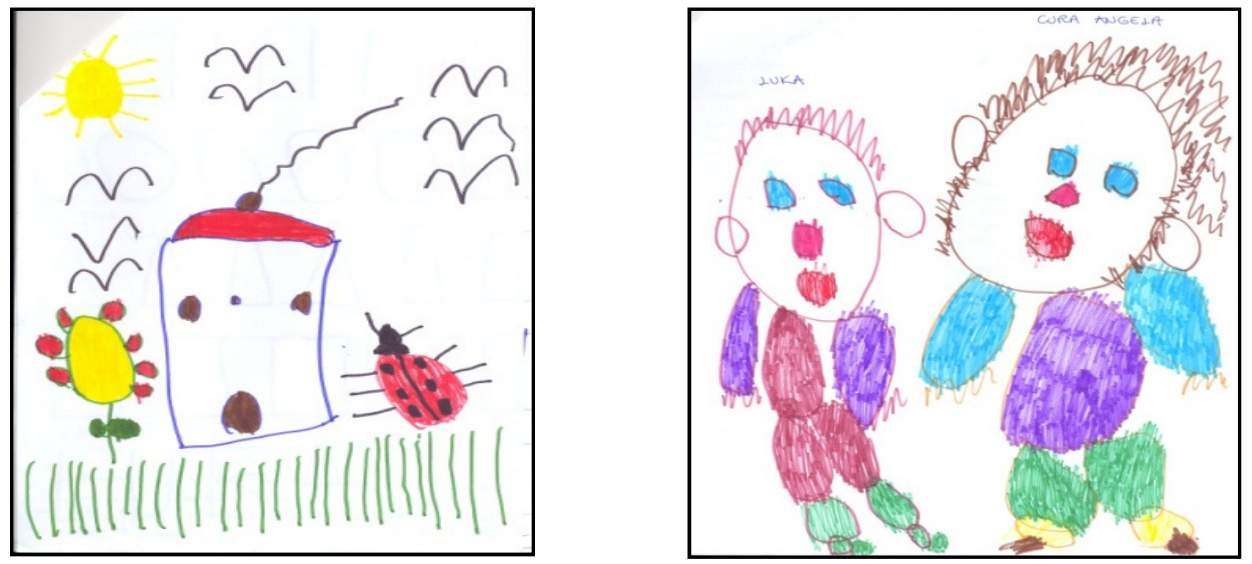

The success of the autistic child in the adoption of drawing can be seen in Figures 3 and 4. Figure 3 (from the record of 5 March 2001) shown that the child drew a house, a flower, a bird, a ladybug and grass. During this work the kindergarten teacher set him a task what to draw and he did it all alone. The teachers helped him only in drawing the smoke off the roof and by proposing colours. From the review of the drawing it may be concluded that drawings are neat and that all the lines and circles on the drawing are regular and complete. Also, all the objects on the drawing are fully and properly coloured. In Figure 4 (from the record of June 5, 2001) the child drew himself (on the left) and his 'girlfriend' Angel (on the right). Important observations of the kindergarten teachers were that all parts of the body were connected and that the body had all the basic features. Also, it is noteworthy that the child worked independently except for the teachers' suggestions about the length of the girl's hair.

By monitoring the development of skills for writing letters and numbers, and drawing a certain set of contents, we can observe a remarkable progress in the 
development of the child's graphomotor skills, especially during the third phase which started in October 2000. Finally, by implementing the preparation program for school the child adopted all the set targets, as well as the graphomotor skills.

\section{Changes in speech}

At the time of the child's arrival in the kindergarten he did not verbally communicate. In this initial stage, he used a small number of words the pronunciation of which was often difficult to understand. His desires and needs he would express by pulling the teacher's hand and by leading her to a specific location or object. In this initial period the kindergarten teachers, after establishing eye contact and arousing positive affective state, encouraged the child to pronounce certain words in the form of a game. As a result of this approach, the child started to use certain words in relation to the kindergarten teachers and simple phrases such as "Give me...".

Noticeable development of speech was accelerated by teachers' work on naming objects or pictures which started in October 2000, i.e. at the beginning of the third phase of development of affective relations with the child. In the beginning he named a letter along with an object. So, at the beginning (in October 2000) for the letter A he pronounced "A automobile", which followed (in February 2001) "A as automobile" that at the end he would (in June 2001) pronounce: "This is letter A like automobile". These examples show that his speech development proceeded slowly and gradually.

New words were learned using a particular object from picture books or his environment. He began to adopt first sentences in a way that the teachers first uttered particular sentences and then he would repeat them. This activity was constantly supported by teachers, which was accompanied by a visible positive child's excitement. The child loved to pronounce sentences associated with the contents in picture books. At the end of the process of the child's preparation for school (in August 2001) he was able to pronounce and write some simple sentences. These were the sentences consisting of 2-3 words, which for him represented a big improvement, considering that at the beginning he could say but a few words that would be pronounced incomprehensively.

Gradually through practice the kindergarten teachers taught the child to say his name, when asked. In learning how to respond to a question he needed stimulus form the teachers, who would first pronounce the beginning of the sentenceresponse and then he would include himself with one or two words that were supposed to follow. At the end, the child was able to respond independently to certain previously learned sets of questions-answers, which then represented the beginning of the child's verbal communication with his kindergarten teachers.

He learned counting along with naming letters. He was able to name numbers to 10 , but he had a problem with counting. At the beginning the problem for him was to link a certain number to a particular object so he attributed several numbers to the same object. Only in April / May 2001 he succeeded in counting with the help 
of picture books and real (concrete) objects. Then he began to count the exact amount of different sets of objects in picture books. The problem was with the schematic (abstract) objects which were difficult or even impossible for him to count. The same was with other objects and contents which did not arouse his interest.

At the end of his stay in the kindergarten he was able to name letters in the picture book ' $\mathrm{ABC}$ ' and objects in his environment, as well as to count, introduce himself and use simple sentences in the 'question-answer game'.

\section{Conclusion}

Based on the kindergarten teachers' diary consisting of records of their work with the autistic child, we can conclude that with an appropriate approach in the form of gradual development of positive affective (dyadic) relations, it is possible to achieve a significant positive change in autistic children in the area of socialization, graphomotor skills, naming objects, letters and numbers, as well as social speech. Only these achievements made it possible for the autistic child to be included in regular elementary school with the custom-made program. It is important to note that the autistic child completed elementary school education last year and continued education to become a cook assistant.

The case report of the autistic child indicates that considerable changes in the child, in relation to his primary state in the first kindergarten, can be attributed to the change in the approach to the building up and maintaining of specific types of affective relationships with him. In the first kindergarten, the kindergarten teachers' approach was dominated by a superficial and emotionally neglected relationship with the autistic child, which was justified by his 'mental retardation' and some 'unknown organic disorder". Thus, we can recognize the negative role of social deprivation in the results of the autistic child's development and in the occurrence of psychotic states. Our experience in the second kindergarten, where the emphasis of the kindergarten teachers was on the building up and maintaining of specific types of affective relationships, demonstrates the importance of such an approach, not only in terms of building a good relationship with the child, but in promoting the development of the child's ability to acquire new knowledge and skills.

Another very important observation obtained by studying the development of affective relationships with the autistic child in the implementation of the preparation program for school, relates to the existence of regularity in the development of such relations. In our example, we noted the existence of three phases: the first is phase of adjustment and establishment of the first affective relationship with the autistic child, followed by the second phase of building a stable affective (dyadic) relationship with the autistic child, and the last, third phase of supporting and encouraging child's new abilities in adoption (internalization) of new knowledge and skills. These three phases express a variety of tasks faced by kindergarten teachers and an autistic child. In the first phase the task is to enable the autistic child to build the first experience of affective (dyadic) union with the 
kindergarten teachers. In this part the focus of the kindergarten teachers' activities is on establishing visual contact with the child and also on their involvement in certain activities of autistic children, encouraging them (reclaimation - Alvarez, 1992) and giving them a positive affective meaning. In this first phase of the development of affective relationship with the autistic child the kindergarten teacher gradually becomes the first object of the child's affective orientation. In the second phase the task of the kindergarten teachers is, through affective stimulation (reclaimation Alvarez, 1992) and alignment (attunement - Stern, 1985) with the autistic child's affective states, to facilitate the development of strong dyadic relations between them and the child thus creating a precondition for development of the child's abilities to control anger and rage in situations of frustration. Only through the development of high-quality dyad with the autistic child, the kindergarten teacher becomes a container (container - Bion, 1959) for the child's anxiety and uncertainty enabling him to deal with new and anxious contents of experiences. In the third phase, after the development of the child's capacity to manage anxiety states, the task of kindergarten teachers is to stimulate certain aspects of the established relationships which support the processes of internalization of the new contents of experience.

At the end, this case review highlights the importance of 'psychological' understanding of autistic manifestations and approaches built upon such understanding for treatment, care and education of autistic children. With this approach the child, who initially (early June 2000) (1) could not make contact with other persons and children around him in the kindergarten, refusing every approach or offered common activities and obligations, then who (2) could not draw or write except fill in the default areas with a certain color, and finally who (3) could not communicate verbally or name certain objects, at the end of the preparation program for school (the end of August 2001) achieved significant changes in levels of socialization, graphomotor and verbal abilities, and after all could be included in regular elementary school with a custom-made program. However, the success in the implementation of this preparation program for school may be attributed to the development of positive affective relation between the autistic child and the kindergarten teachers. Their relation was based on the supervision of kindergarten teachers' approach to the autistic child, which consisted of certain 'psychological' concepts of the autistic genesis developed in the field of psychoanalytic psychology.

At the end of this case review I consider that it would be necessary to direct ourselves to some present 'psychological' concepts of autism and their different contributions for the inclusion of autistic children in some pre-school programs.

\section{Bibliography}

1. Acquarone, A. (2007). Parent Infant Clinic. The School of Infant Mental Health, London. (www.infantmentalhealth.com)

2. Alavarez, A. (1992). Live Company. London \& New York: Tavistock/Routledge. 
3. Barrows, P. (2002). Becoming verbal: autism, trauma and playfulness. Journal of Child Psychotherapy, 28(1); 53-72.

4. Bettelheim, B. (1967).The Empty Fortress: Infantile Autism and the Birth of the Self. New York: Free Press, 1972. $40: 308-15$

5. Bion, W.R. (1959) Attacks on linking. International Journal of Psycho-Analysis

6. Bujas-Perković, Z., Tardi, S. (2004). Pervazivni razvojni poremećaj. U: Nikolić, S., Marangunić i sur. (ur). Dječja i adolescentna psihijatrija. Zagreb: Školska knjiga. 141-163.

7. De Cesarei, A.O. (2005). Early trauma and narcissism-autism bipolarity. International Journal of Psycho-Analysis; 86: 657-751.

8. Gomberoff, M., Gomberoff, L.P. (2000). Autistic devices in small children in mourning. The International Journal of Psycho-Analysis; 81; 907-20.

9. Hallett, J. i Viren, D. (2005). Making sense of autism. Medicine and Health, Rhode Island; 88(5); 43-46.

10. Harshman, E. J. (2002). Autism: A Cognitive or Behavioral Disorder. Medical Sentinel, 7; 126-127.

11. Herbert, J. D., Sharp, I. R., Gaudiano, B. A. (2002) Separating Fact from Fiction in the Etiology and Treatment of Autism: A Scientific Review of the Evidence. The scientific review of mental health practice, $1(1) ; 23-43$

12. Houzel, D. (2004). The psychoanalysis of infantile autism. Journal of Child Psychotherapy. 30(2); $225-237$.

13. Kanner, L (1949). Problems of nosology and psychodynamics in early childhood autism. American Journal of Orthopsychiatry 19(3); 416-26.

14. Kanner, L. (1943). Autistic disturbances of affective contact. Nervous Child 2; 217-50.

15. Klein, M. (1930). The importance of symbol-formation in the development of the ego. In: The Writings of Melanie Klein, vol. I. Love, Guilt and Reparation and Other Works 1921 1945. London: Hogarth (1975).

16. Kohut, H. (1990). Analiza sebstva. Biblioteka psiha, Naprijed; Zagreb.

17. Mahler, S., Pine, M.M. i F., Bergman, A. (1973). Psychological Birth of Humane Infant, New York: Basic Books.

18. McDowell, M. J. (2004). Autism, early narcissistic injury and self-organization: a role for the image of the mother's eyes? Journal of Analytical Psychology, 49(4); 495-519.

19. Meltzer, D. i sur. (1975). Explorations in autism. Perth: Clunie Press.

20. Mori S. (2001). The role of the self-object experience in the therapy of an autistic child: from lying at to launching a 'spaceship'. Journal of Child Psychotherapy, 27(2); 159-173.

21. Nikolić, S. (1988). Mentalni poremećaji kod djece i omladine. Školska knjiga, Zagreb.

22. Nikolić, S.(2000). Autistično dijete, Zagreb: Prosvjeta

23. Reid, S. (1999) 'Autism and trauma: autistic post-traumatic developmental disorder'. In Alavarez, A. i Reid, S. (ur.) Autism and Personality. London and New York: Routledge

24. Rhode, M. (2005). Mirroring, imitation, identification: the sense of self in relation to the mother's internal world. Journal of child psychotherapy, 31(1); 52-71.

25. Rutter, M. L., Andersen-Wood, L., Becket, C., Bredenkampf, D., Castle, J., Grothues, C. I. (1999). Journal of Child Psychology and Psychiatry, 40; 537-549.

26. Špelić, A. (2008). Mogućnosti psihoanalitičke psihoterapije autizma: Novi psihoterapijski pristup. Gregurek, R. (ur.). Izazovi psihoterapije u stoljeću uma. Zadar, 67-67 
27. Špelić, A. (2010). Psihoanalitička psihoterapija autizma danas: Ograničenja i nove mogućnosti u suvremenom znanstvenom i stručnom okruženju. U: Skodlar, B. (Ur). Navezanost (82-96). Združenje psihoterapeutov Slovenije, Ljubljana.

28. Stern, D. N. (1985). The Interpersonal World of the Infant. New York: Basic Books.

29. Tustin, F. (1972). Autism and Childhood Psychosis. London: The Hogarth Press.

30. Tustin, F. (1992). Autistic States in Children. London \& New York: Routledge

31. Urwin, C. (2002). A psychoanalytic approach to language delay: When autistic isn't necessarily autism. Journal of Child Psychotherapy, 28(1); 73-93

32. Waters, L. (1990). Reinforcing the Empty Fortress: an examination of recent research into the treatment of autism. Educational Studies, $\underline{16}(\underline{1)} ; 3-16$.

33. Zepf, S. i Zepf, F. D. (2008). Autism in Infancy: The Psychodynamics from a Freudian Viewpoint. Canadian Journal of Psychoanalysis, 16(2); 194-223.

Metodički obzori 7(2012)2

Pregledni rad

UDK: 616.895-053.4:371.3

Primljeno: 3. 2. 2011.

\section{PRIPREMA AUTISTIČNOG DJETETA ZA ŠKOLU}

Dr. sc. Aldo Špelić, prof. v. ̌́. Odjel za odgojne i obrazovne znanosti, Sveučilište Jurja Dobrile u Puli (Hrvatska) e-mail: aspelic@unipu.hr

Martina Košeto, diplomantica Odjel za odgojne i obrazovne znanosti, Sveučilište Jurja Dobrile u Puli (Hrvatska) e-mail: martina.koseto@hotmail.com

\section{Sažetak}

Cilj ovog rada je prezentirati nove mogućnost individualiziranog pristupa odgojitelja u pripremi za školu autistične djece. U radu je prezentiran slučaj autističnog dječaka koji je uz individualni psihoterapijski tretman bio uključen u individualizirani vid rada s dvije odgojiteljice na ostvarenju programa pripreme za školu. Kroz provođenje programa koji je bio primarno zasnovan na razvoju afektivne komunikacije u dijadnom odnosu dobiveni su pozitivni rezultati u djetetovoj afektivnoj vezanosti uz odgojiteljice čemu su slijedili pozitivni rezultati na području usvajanja osnove grafomotorike, imenovanja i socijalnog govora, čime je omogućen upis djeteta u redovnu osnovnu školu. Ovaj rad predstavlja poticaj mnogim drugim takvim pristupima u pripremi autistične djece za redovno osnovnoškolsko obrazovanje

Ključne riječi: autizam, priprema za školu, rani djetetov razvoj 